\title{
Nordisk tidsskrift for utdanning og praksis
}

Nordic Journal of Education and Practice

Forskningsartikkel FAGFELLEVURDERT

Vol. 13, No. 1, 2019, s. 62-82

\section{Utdanningsreformer og voksnes læring. Gap mellom intensjoner og resultater når ideologi og politikk fyller kunnskapshullene}

\author{
Christin Tønseth
}

\begin{abstract}
SAMMENDRAG
Store utdanningsreformer kan ha mange uintenderte resultater til tross for at reformenes retorikk synliggjør velgjørende og overbevisende incentiver, samt tilsynelatende god styring og kontroll. I denne artikkelen belyses politikkutforming gjennom implementering av tre store utdanningsreformer: Reform 94, Kompetansereformen og Kunnskapsløftet. Med bakgrunn i teori om sosial konstruksjon, gjennomgang av evalueringsrapporter, aktuelle internasjonale rapporter og relevant forskningslitteratur, identifiseres en rekke gap mellom intensjoner og resultater når det gjelder voksnes læring. Artikkelen diskuterer hvorvidt disse gapene kan forklares ut ifra selve politikkutformingen. Politikkutformingen relatert til de aktuelle reformene er konstruert gjennom en diskursiv praksis der det balanseres mellom ulike hensyn og verdier, som veves sammen med et fragmentert og til dels manglende kunnskapsgrunnlag. Retorikken og de vage formuleringene kamuflerer i tillegg en del kritiske punkter mellom vitenskap og politikk, der vitenskapelige kunnskapsfragmenter konstrueres inn i en evidensbasert politikkutforming.
\end{abstract}

Nøkkelord: voksnes læring, livslang læring, utdanningspolitikk, utdanningsreformer, teori om sosial konstruksjon.

\section{ABSTRACT}

Major political education reforms have many unintended results, despite the fact that the political rhetoric highlights convincing incentives and apparently good governance and control. In this article, policy design is highlighted through the implementation of three major education reforms; Reform 94, The Competence reform and The Knowledge Promotion reform. Based on social construction theory, relevant research, and international and national policy documents, gaps are identified between intentions and outcomes regar-

(C2019 Christin Tønseth. This is an Open Access article distributed under the terms of the Creative Commons Attribution-NonCommercial 4.0 International License (https://creativecommons.org/licenses/by-nc/4.0/).

Tønseth, C. (2019). Utdanningsreformer og voksnes læring. Gap mellom intensjoner og resultater når ideologi og politikk fyller kunnskapshullene. Nordisk tidsskrift for utdanning og praksis, 13[1], 62-82. https://doi. org/10.23865/up.v13.1837 
ding adult learning. The article further discusses whether these gaps can be explained by the actual policy design. The political rhetoric that encircles the three educational reforms includes abstract and vague formulations which contradict some critical points between science and politics, where scientific knowledge fragments are constructed into evidencebased policy design.

Keywords: Adult Learning, Lifelong Learning, Education Policy, Educational Reforms, Social Construction theory.

\section{Innledning}

I enhver moderne politisk diskurs generelt og i utdanningsreformer spesielt ligger det implisitt et forbedringsønske knyttet til politiske og samfunnsmessige utfordringer som aktualiseres i en tidsbestemt politisk kontekst. En utdanningsreform er en politisk intendert og omfattende styrt plan som rettes mot endring av bestemte sider ved utdanningssystemet. Utdanningsreformer skal møte behov i fremtiden og samtidig løse problemer fra fortiden (Tønseth, 2011).

Jeg har jobbet som forsker i den nasjonale evalueringen av Reform 94, med fokus på reformens konsekvenser for voksne. I tillegg har jeg gjort et avhandlingsarbeid som tar utgangspunkt i Kompetansereformens intensjoner (Tønseth, 2011). På grunnlag av denne bakgrunnen, samt min stilling som forsker i evalueringen av Kunnskapsløftet, med fokus på fag- og yrkesopplæringen, har jeg samlet erfaringer og gjort noen refleksjoner over selve politikkutformingen. De tre utdanningsreformenes hovedmålgrupper var forskjellige, og det var først og fremst Kompetansereformen som hadde voksne som sin primære målgruppe. Likevel var det slik at både Reform 94 og Kunnskapsløftet hadde intensjoner som omfattet den voksne befolkningen.

Store utdanningsreformer er utfordrende å planlegge og implementere. Utdanningssektoren er et omfattende system, med mange aktører og delelementer som henger sammen, samtidig som ulike kontekster innenfor samme sektor krever ulike typer intervensjoner. Dessuten er reformprosesser både kostbare og ofte konfliktfylte, og det er heller ikke alltid like godt samsvar mellom intensjonene bak reformene, tilhørende tiltak og implementeringsstrategiene (Fudge \& Barrett, 1981; Sætren, 2006). Iverksatte utdanningsreformer kan derved ha mange subversive og uintenderte effekter til tross for at reformenes retorikk synliggjør velgjørende, overbevisende incentiver og tilsynelatende god styring og kontroll.

Fordi reformer iverksettes ovenfra og ned, blir det til dels stor avstand mellom de som initierer og utformer, de som iverksetter, og de som mottar reformer (Cuban, 1993; Hølleland, 2008). Internasjonal implementeringsforskning viser at nasjonale 'large-scale' utdanningsreformer som implementeres fra nasjonalt beslutningsnivå, fortolkes og transformeres når de møter underliggende forvaltningsnivåer (Datnow, 2000, 2002; Elmore, 1996; Fullan, 1999, 2001; Hargreaves \& Fink, 2000;). Samtidig viser reformforskningen at pedagogisk praksis og organisering preges av stabilitet til 
tross for nasjonale reformbestrebelser. Nasjonale reformer har derfor en tendens til å bli introdusert igjen og igjen (Cuban, 1993; Datnow, 2002; Klette, 2003; Tyack \& Cuban, 1995).

Mye forskning på utdanningsreformer har blitt rettet mot implementeringsprosesser, styringsmekanismer og aktørers adferd. Som et bidrag til videre politikkutforming på området voksnes læring, er hensikten med denne artikkelen å diskutere konstruksjon av reformpolitikk relatert til kunnskapsgrunnlaget som reformene bygger på. Teori, offentlige politiske dokumenter, evalueringsrapporter og annen forskningslitteratur blir benyttet som grunnlag for å reflektere over ulike gap mellom intensjoner og resultater i de tre utdanningsreformene, samt hvorvidt dette kan begrunnes ut ifra en politikkutforming basert på sosial konstruksjon. Det avgjørende for valg av dokumenter har vært at det har vært sammenheng mellom dokumentene, type dokumenter og problemstillingen. Problemstillingen i denne artikkelen består av to spørsmål:

Hvilke gap mellom intensjoner og resultater som gjelder voksne kan identifiseres $i$ de tre utdanningsreformene?

Hvordan kan vi forstå disse gapene ut ifra det kunnskapsgrunnlaget som politikkutformingen bygger på?

\section{Politikkutforming som sosial konstruksjon, diskurs og makt}

Innenfor alle de tre utdanningsreformene kommuniseres et kunnskapsgrunnlag som aktualiseres og fremheves gjennom reformenes intensjoner på nasjonalt nivå. I artikkelen vil begrepene sosial konstruksjon, diskurs og makt til sammen utgjøre et teoretisk fundament og grunnlag for å drøfte spørsmålet om hvordan dette kunnskapsgrunnlaget skapes og inkluderes i politikkutformingen og reformprosessene.

Teorien om sosial konstruksjon tar utgangspunkt i at vår virkelighetsforståelse er sosialt konstruert, og at denne virkelighetsforståelsen bestemmer våre handlinger og strategier (Berger \& Luckmann, 1966). Individers og samfunnets oppfattelse og forståelse av hva som er virkelig og sant, er i seg selv et produkt av individers og sosiale gruppers sosiale interaksjon. Både konstruksjonsprosessene og de sosiale realiteter som avledes av den sosiale konstruksjonen anses som viktig å analysere (Giddens, 2001).

Foucaults diskursbegrep har vært viktig for sosialkonstruksjonistene. En diskurs i Foucaults forstand er et sett med kunnskaper, meninger, metaforer, bilder og historier som produserer en bestemt versjon av en hendelse (Burr, 2006). Noen diskurser er mer fremtredende enn andre og vil dermed marginalisere andre diskurser. På den måten anses makt og kunnskap å være uløselig knyttet sammen. Kunnskap om 
virkeligheten blir sosialt konstruert gjennom diskursiv praksis. Makten er produktiv og produserer kunnskap som legitimerer makten (Foucault, 1999). Det er denne formen for makt som utøves gjennom ulike samfunnsdiskurser, for eksempel i utdanningspolitikken, som er i fokus i denne artikkelen. Politiske diskusjoner, begrepsbruk og definisjonsmakt skaper forestillinger om utfordringer og relevante midler for å løse dem. Utdanning kan dermed forstås både som et instrument og et objekt for makt. Ut fra dette perspektivet kan ethvert utdanningssystem forstås som et politisk middel for å opprettholde eller justere anvendelsen av de ulike utdanningsdiskursene, og den kunnskapen og makten de bringer med seg (Ulleberg, 2007).

Diskurser, teorier og forestillinger materialiserer seg og får sitt uttrykk gjennom handling og praksis, strategier og politikk. Foucault beskrev hvordan fenomener som ofte fremstilles som naturlige, universelle og uforanderlige, egentlig er produkter av sosiale praksiser som varierer i tid og rom (Ball, 1994). I politisk sammenheng er det $\mathrm{i} ø$ kende grad en forestilling om at evidensbasert kunnskap gir det beste kunnskapsgrunnlaget. Dette kunnskapsgrunnlaget er ment å tjene politikkens behov for argumenter som legitimerer politiske incentiver og politisk styring (Bilson, 2002). Ulike 'evidens' blir argumentert inn i de sosiale konstruksjonene i den politiske konteksten som legitimerer en virksomhet der de beste og mest effektive løsningene anvendes (Bilson, 2002). Forestillinger om virkeligheten kan skapes gjennom debatt, retorikk og argumentasjon som baserer seg på elementer fra forskning, praksis, kontekst, internasjonale politiske føringer og grunnleggende politisk ideologi. I politikk som gjelder voksnes læring, utgjør rapporter og direktiver fra de internasjonale organisasjonene OECD, EU og UNESCO en sterk påvirkningskraft (Tønseth, 2011). I tillegg kommer nasjonal og internasjonal forskning på feltet, samt ulike innspill og erfaringer fra praksisfeltet. Med visjonen om 'Livslang læring' skapes et narrativ som lover en forbedring for alle, der alle skal inkluderes og oppnå sine ønsker i livet gjennom læring (Fejes, 2006).

Faren i slike politiske konstruksjonsprosesser er at en tillitvekkende retorikk kan dekke over reelle kritiske punkter i møtet mellom vitenskap og politikk, der kunnskapsfragmenter inkluderes i en argumentasjonsrekke. Innenfor reformene, fremsettes en retorikk som retter seg mot de voksne. Det fremsettes eksempelvis en rekke utsagn om voksnes vilkår for læring, behov og forutsetninger, kompetansebehov og livslang læring. Slik retorikk og begrepsbruk inngår i en sosialt konstruert evidensbasert politikkutforming (EU, 2007; Hansen, 2007).

\section{Dokumentanalyse}

Fokus i arbeidet med denne artikkelen har vært å sammenfatte relevante politiske dokumenter og funn fra egen og andres forskning for å besvare problemstillingen. Valget av dokumentanalyse som metodisk innfallsvinkel begrunnes dermed ut fra problemstillingen og et datamateriale som består av sekundærkilder. 
Ved bruk av dokumentanalyse må dokumentene velges og vurderes etter den konteksten de settes i (Grønmo, 2004; Thagaard, 2002). I løpet av den 4-årige evalueringen av Reform 94 ble det publisert mer enn 40 evalueringsrapporter fra forskningsinstitusjonene som deltok i evalueringen. Kompetansereformen ble ikke evaluert gjennom følgeforskning på samme måte som de to andre reformene, men en god del forskningslitteratur som beskriver effektene av reformen er publisert. Kunnskapsløftet ble evaluert av flere forskningsmiljøer. Evalueringen resulterte i til sammen 44 evalueringsrapporter og fire synteserapporter. De aktuelle evalueringsrapportene er både utarbeidet underveis i implementeringen og etter at reformene ble gjennomført. Andre valgte dokumenter har vært Stortingsmeldinger, NOUer, samt sentrale rapporter fra UNESCO, OECD og EU. I alt 19 sentrale politiske bakgrunnsdokumenter ligger til grunn for dokumentanalysen. I lys av teori om sosial konstruksjon er evalueringsrapporter analysert på leting etter resultater fra reformene, mens de politiske dokumentene er analysert på leting etter intensjoner og aktuell politikkutforming.

Analysen er inspirert av Boeije (2010) og hans bok Analysis in Qualitative Research. Datamaterialet er følgelig redusert ved åpen koding med fokus på omtale av politikkdesign, intensjoner og resultater som omfatter voksne. Denne fremgangsmåten har gitt meg mulighet til å dissekere og beskrive forholdet mellom ulike og like deler av dokumentene (Boeije, 2010), for derved å identifisere mulige gap mellom intensjoner og resultater. Gjennom aksial koding har jeg lett etter ulikheter og gap mellom intensjoner og resultater i det sorterte utvalget, og deretter drøftet den teoretiske tilknytningen disse gapene kan ha til politikkutformingen. Denne artikkelen har dermed ikke har hatt som mål å utvikle ny teori, men å diskutere funn fra dokumentanalysen opp mot eksisterende teori.

Vitenskapelig kunnskap skal være basert på systematisk kritisk refleksjon, og forbindes med relevans, transparens, validitet, refleksivitet, overførbarhet, pålitelighet og ærlighet sammenlignet med de betingelsene som har skapt, produsert, utviklet og konstruert kunnskapen (Thagaard, 2002). Forskeren må samtidig hele tiden kritisk vurdere betydningen av egen posisjon under hele forskningsprosessen (Thagaard, 2002). I denne studien har dette først og fremst handlet om å reflektere over egen forforståelse, egen forskning og evalueringserfaring og ivareta en transparent refleksivitet gjennom drøftingene.

\section{Reform 94}

Behov for samordning og fleksibilitet i videregående opplæring var en prosess som pågikk i svært mange land i forkant av Reform 94 (Deichmann Sørensen, 1999). De felles bestrebelsene i Europa handlet om å heve utdanningsnivået i samfunnet og oppfylle kvalifikasjonskravene i arbeidslivet. Utfordringer i norsk videregående opplæring handlet om at spesialiseringen innenfor yrkesfagene var for omfattende, det var for mange tilbud som gjorde det uoversiktlig for elevene. Det var stort frafall og 
svak gjennomstrømning, og sammenhengen mellom opplæring i skole og opplæring i arbeidslivet var for dårlig. Samtidig var arbeidsledigheten økende på begynnelsen av 1990-tallet (Røed, 1993), noe som aktualiserte behovet for fornyet kompetanse også for voksne. Krav om faglærte medarbeidere i ulike sektorer førte til økt behov for fagbrev blant voksne, ufaglærte arbeidere. Bakgrunnen for omleggingen av den norske videregående opplæringen var hovedsakelig ønsket om en mer effektiv opplæring hvor en kunne få utnyttet befolkningens kompetanse på en bedre måte (NOU 1991:4). Den store vektleggingen av arbeidslivets behov og økt sysselsetting la dermed premissene for ny tilbudsstruktur og organisering av den videregående opplæringen gjennom Reform 94.

Reformen ble betegnet som en rettighetsreform, innholdsreform og en strukturreform i videregående opplæring. Intensjonene var knyttet til (1) tilbud til alle i aldersgruppen 16-19 år, (2) at alle utdanningsløp skulle ende opp i studiekompetanse og/eller fagbrev, samt (3) en reduksjon i antall «kryss og tvers» elever, som gikk fra ett grunnkurs til et annet. Selv om reformen primært skulle gjelde for rettighetselevene mellom 16-19 år, skulle det tas høyde for andre grupper. Blant disse var voksne som manglet fullført videregående opplæring og som hadde behov for ny kompetanse og omskolering. Omfanget av videregående opplæring for voksne ble avhengig av størrelsen på kullene av rettighetselever. Dersom kullene av rettighetselever var store, vil dette begrense omfanget av plasser for voksne. Intensjoner i reformen som ble sett som særlig positive for voksne i utgangspunktet, var at fleksibilitet skulle ivaretas ved at oppbyggingen av samme kompetanse kunne gjøres på ulike måter, ved moduler, komprimerte løp eller delkompetanse. I tillegg skulle man samordne tilbud, slik at de ble lettere tilgjengelige for flere. Fagbrev kunne gjennomføres enten innen det videregående opplæringssystemet eller ved å dokumentere relevant praksis innen faget.

\section{Resultatene av Reform 94}

Reform 94 var på flere måter en suksess, blant annet ved økt gjennomstrømning av elever i videregående skole (Støren et al.,1998; Støren \& Sandberg, 2001). Man erfarte gjennom reformen at et økt samarbeid og samordning mellom ulike instanser ga positive effekter for kvalitet, tilgang og ressursbruk innen voksenopplæring (Svensen, 2000). Likevel pekte evalueringen av reformen blant annet på et stort frafall, spesielt blant gutter på yrkesfag (Lødding, 1998; Støren \& Sandberg, 2001) og at reformen var for lite fleksibel både innholdsmessig og strukturelt (Tønseth, 1999). Evalueringen pekte på behov for bedre tilrettelegging for den enkelte og bedre samsvar mellom bredde og spesialisering innenfor yrkesfagene (Grøgaard et al., 1999; Grøgaard et al., 2002; Olsen et al., 1998). Likevel var reformen ekskluderende for voksne som endte med å havne sist i køen ved inntak, med lite fokus på tilrettelegging for voksnes behov (Engesbak, 1995; Engesbak et al., 1998, Tønseth, 1999).

De fleste voksne deltok i ordinære klasser blant rettighetselevene, og ikke i opplæring som var tilpasset deres behov. Frafallet blant voksne viste seg å være 
foruroligende høyt, særlig rett etter starten av opplæringen (Madsen \& Tønseth, 1998). Finansieringssystemet var slik at noen voksne fikk gratis opplæring, mens andre måtte betale for opplæringen selv. De voksne opplevde at det var lite tilgjengelig informasjon og oversikt over alle tilbudene som eksisterte, og de savnet et rådgivningsapparat relatert til egen karriereplanlegging (Madsen \& Tønseth, 1998).

De tydeligste gapene mellom intensjoner og resultat når det gjelder voksne i Reform 94, var at intensjonene om gode tilrettelagte tilbud for voksne ikke ble innfridd. Ved at de sto sist i køen ved inntak til videregående opplæring, var det heller ikke alle som fikk de mulighetene som reformen la opp til. Den store omstruktureringen av videregående opplæring som skjedde på 1990-tallet hadde store konsekvenser for voksne. Reform 94 må forstås på bakgrunn av masseutdanningssamfunnet og problemer med køer i den videregående skolen. Diagnosen var at den videregående skolen var overbelastet, både som følge av et stort antall voksne elever, men også som følge av svak gjennomstrømning. Antagelsen om at de mange voksne i yrkesutdanning ville avta når ungdom ble prioritert gjennom rettighetslovgivningen holdt ikke stand. Det ble ikke færre voksne verken blant lærlinger, praksiskandidater eller i de skolebaserte utdanningene (Høst, 2010, s. 9).

\section{Kompetansereformen}

Bakgrunnen for Kompetansereformen var en økende bevissthet i arbeidslivet og blant politikere om betydningen av kompetanse og livslang læring (Hagen \& Skule, 2008; OECD, 2000; St.meld. nr. 42, 1997-98). Kompetansereformen, iverksatt i år 2000, skulle være en arbeidslivsreform, der verdiskaping, sysselsetting og økonomisk vekst var viktige mål (St.meld. nr. 42, 1997-98; NOU, 1997:25). Målet var å tilpasse opplæringstilbudene bedre til voksnes behov blant annet ved åpne og fleksible læringsformer, og tilbudene ble organisert slik at de kunne kombineres med arbeid og/eller omsorg. Et annet mål var å legge rammevilkårene best mulig til rette for kompetanseutvikling for den enkelte. Gjennom kompetanseutviklingsprogrammet (KUP) skulle man bidra til nyskaping i og videreutvikling av markedet for etter- og videreutdanning. Det skulle også etableres et nasjonalt system for dokumentasjon og verdsetting av voksnes realkompetanse (Realkompetanseprosjektet) (Helland \& Opheim, 2004). Et annet mål var å bidra til økt kompetanse og bevissthet om de ferdigheter, kunnskaper og holdninger som trengs for demokratisk deltakelse både i arbeids- og samfunnsliv. Gjennom parolen 'Ny sjanse - ny kompetanse', skulle alle voksne som trengte det få mulighet til grunnskole og videregående opplæring. God informasjon om utdanningsmuligheter og om Kompetansereformen, sammen med et godt veiledningsapparat, var en grunnleggende intensjon. Kompetansereformen skulle etter sigende ha et bredt perspektiv. Den skulle først og fremst være rettet mot arbeidsstyrkens behov for 'løpende kompetanseutvikling', men også mot utsatte grupper som opplevde problemer med å komme i arbeid. I Kompetansereformen 
var de individrettede verdiene av utdanning ment å bidra til utjamning av forskjeller i samfunnet gjennom å gi like muligheter til alle (Tønseth, 2011).

\section{Resultater av Kompetansereformen}

I sin beskrivelse av status for Kompetansereformen i 2008, hevdet Hagen og Skule (2008) at reformen førte til at voksnes individuelle rettigheter ble styrket på utdanningsområdet, med rett til grunnskole og videregående opplæring. Arbeidstakere fikk økte permisjonsrettigheter, og det ble utviklet ordninger for vurdering og verdsetting av realkompetanse. Reglene i Lånekassen var bedre tilpasset voksnes behov, og arbeidsgiverfinansiert utdanning og opplæring ble et skattefritt gode. Kompetanseutviklingsprogrammet (KUP) bidro til at det i deler av arbeidslivet ble utviklet mange nye opplæringstilbud, som var bedre tilpasset arbeidslivet og voksnes behov. Kunnskap om behovet blant voksne for grunnopplæring ble ansett som viktig for å kunne gi et tilfredsstillende tilbud, og for å kunne gi målrettet informasjon til de med behov og rett. Riksrevisjonen (2008) påpekte i sin rapport om Kunnskapsdepartementets ivaretakelse av de voksne etter reformen, at usikkerheten rundt voksnes behov for opplæring var like usikkert som før reformen. Hagen og Skule (2008) påpekte at det var den såkalte «ny sjanse» -delen av Kompetansereformen som i minst grad hadde gitt de resultater som ble forespeilet. «Ny sjanse» dreier seg her om voksnes rett til å fullføre grunnskole og videregående skole. Det var få som benyttet seg av retten til grunnskoleopplæring, og det hadde heller ikke vært noe betydelig økning i antall voksne som tok videregående opplæring. Forklaringer på dette var at voksne hadde liten kjennskap til sine rettigheter og muligheter, de manglet tilrettelegging og motivasjon eller de hadde ikke muligheter for permisjon (Hagen \& Skule, 2008). Kompetansereformen ble dermed ikke den arbeidslivsreformen som partene proklamerte at den skulle bli (Tønseth, 2011).

\section{Kunnskapsløftet}

Internasjonale undersøkelser (PISA-undersøkelsene) viste at norske elever hadde dårlige faglige resultater i forhold til de ressursene som ble brukt på utdanning $\mathrm{i}$ Norge. Det var store forskjeller som følge av sosial ulikhet, dårlig progresjon i videregående opplæring, høyt frafall og ikke godt nok tilpasset opplæring for alle. Det var en bred politisk enighet bak Kunnskapsløftet som ble innført høsten 2006 for hele grunnopplæringen, grunnskolen og videregående opplæring. Kunnskapsløftet ble betegnet som en styringsreform, en strukturreform og en innholdsreform i grunnopplæringen (grunnskole og videregående opplæring). Mye av det direkte forarbeidet for Kunnskapsløftet kommer fra Stortingsmelding nr. 30, Kultur for loering, og her ble mange av prinsippene og hovedlinjene i Kunnskapsløftet beskrevet. Kunnskapsløftet er et eksempel på en utdanningsreform, som på den ene siden ligger i 
forlengelsen av tidligere nasjonale utdanningsreformer og på den andre siden aktualiserer den internasjonale reformdiskursen.

Målet for Kunnskapsløftet var at alle elever skulle utvikle grunnleggende ferdigheter og kompetanse for å kunne ta aktivt del i kunnskapssamfunnet. Norsk skole skulle være en inkluderende skole med plass til alle og med vekt på det faglige. Spesielt skulle Kunnskapsløftet bidra til å sikre 'tilpasset opplæring' for alle elever - også for de voksne innenfor grunnopplæringen (Hodgson et al., 2012). Grunnleggende ferdigheter skulle styrkes gjennom god lese- og skriveopplæring (OECD, 2001; UFD, 2003). Nye læreplaner ble utviklet i alle fag, med tydelige mål for elevenes og lærlingenes kompetanse. Dette innebar nye fag og ny timefordeling og med ny tilbudsstruktur i videregående opplæring. Det ble lagt vekt på lokal valgfrihet med hensyn til arbeidsformer, læremateriell og organisering av opplæringen. Gjenkjennbare intensjoner fra tidligere reformer var bedre gjennomstrømning (eller mindre frafall/ bortvalg) i videregående opplæring, bedre læringsutbytte (eller høyere kvalitet på de ferdige kandidatene) og bedre muligheter for den enkelte til å bli mer attraktiv og kvalifisert for arbeidslivet (UFD, 2003).

I utgangspunktet var ikke de voksne en primær målgruppe i Kunnskapsløftet, men innenfor rammen av reformen ble det vedtatt endret aldersgrense for voksnes rett til videregående opplæring, slik at alle over 16 år som trenger det skulle få gratis opplæring. Fokuset var på økt bruk av realkompetanse/praksiskandidatordning, tilpasset opplæring for voksne, og etablert karriereveiledningstiltak for voksne.

\section{Resultater av Kunnskapsløftet}

Evalueringsrapporter pekte på at reformen stilte nye krav til lokal styring, og at variasjon i kompetansen til skoleeiere, skoleledere og lærere var barrierer som sinket implementeringen av Kunnskapsløftet (Aasen et al., 2012). Først fem år etter at Kunnskapsløftet ble innført, hadde skoleeiere, skoleledere og lærere fått en forståelse av hvordan de skulle håndtere reformen (Dale, Ulstrup Engelsen \& Karseth, 2011; Aasen et al., 2012). Resultater som ble rapportert var at frafallet fra videregående opplæring ikke hadde gått ned (Vibe et al., 2012). Nordenbo (2012) slo i tillegg fast at Kunnskapsløftet kun har medført små endringer, og det var uklart om endringer og resultater i det hele tatt kunne tilskrives reformen. De små endringene pekte i retning av økende sosial ulikhet (Jørgensen, 2000). Forskerne vurderte at dette kunne skyldes at virkemidlene i reformen ikke var spesielt innrettet mot utjevning (Jørgensen, 2000).

For voksnes del var nok bedringen av deres grunnleggende ferdigheter og økte muligheter til karriereveiledning det mest markante resultatet (Teige et al., 2009). Utarbeidelse av system for dokumentasjon og verdsetting av realkompetanse, styrkede rettigheter til utdanningspermisjon i arbeidslivet, og et bedre finansieringssystem ble gjennomført i perioden da Kunnskapsløftet ble implementert. Undersøkelser viste imidlertid store forskjeller fylkeskommunene imellom, som igjen medførte 
at ivaretakelsen av voksnes individuelle rettigheter var avhengig av hvilket fylke de bodde i. I tillegg ble det brukt mye tid og ressurser i fylkeskommunen på å forstå og avklare hvordan voksnes rettigheter etter opplæringsloven skulle håndteres (Dahl et al., 2012; Teige et al., 2009). Voksne med rett til videregående opplæring hadde også rett til realkompetansevurdering. Det var imidlertid en utfordring å skape en forståelse og en praksis som gjorde at voksnes realkompetanse ble vurdert på samme måte i de ulike fylkene. Evaluering av reformen viste også at tilbudet om karriereveiledning fremsto som uoversiktlig og fragmentert (Aasen et al., 2012).

\section{Gap mellom intensjoner og resultat}

Gjennomgangen av reformenes bakgrunn, intensjoner og resultater viser en rekke gap mellom intensjonene og resultatene av reformene når det gjelder voksnes læring. Begrepsbruken i intensjonsbeskrivelsene innenfor de tre reformene er noe ulik, selv om intensjonene «egentlig» beskriver samme fenomen eller visjon. Dette er i seg selv interessant ut ifra antagelser om retorikkens og begrepers betydning i politikkutformingen. Jeg har kategorisert «gapene» i fire kategorier: (1) gap mellom kunnskapsgrunnlag og politikk, (2) gap mellom likhet og mangfold, mellom inkludering og ekskludering, (3) gap mellom individrettede og kollektive intensjoner og (4) gap mellom formelle, ikke-formelle og uformelle loeringskontekster. Disse kategoriene vil bli drøftet hver for seg.

\section{(1) Gap mellom kunnskapsgrunnlag og politikk}

Denne kategorien beskriver gap mellom forskningsfunn og erfaringer fra praksis på den ene siden, og det som planlegges, aktualiseres og gjennomføres politisk på den andre. Forskning viser at voksne er en heterogen gruppe med ulike behov, forutsetninger og vilkår. Likevel gjenfinner vi de fleste voksne i standardiserte læringsopplegg med lite fleksibilitet når det gjelder tid, sted, tilrettelegging og individualisering (Tønseth, 1998; Tønseth, 2011). Forskning viser at voksne trenger mer informasjon om hvilke muligheter de har og hvilke tilbud som finnes (Engesbak et al., 1998). Videre peker forskning på at voksne har ulike erfaringer og en modenhet som bør tas aktivt med i planlegging og gjennomføring av læring (Cross, 1984; Knowles, 1988) noe de relativt sjelden blir invitert til å gjøre i praksis (Tønseth, 2011). Vi vet at det er voksne som befinner seg utenfor arbeidslivet og har lav utdanning som i minst grad deltar i læring (Finbak \& Engesbak, 2006). Altså de som egentlig trenger utdanning mest og de samme som er blitt fremhevet som en særlig målgruppe i de tre reformene. Hvorfor er det så vanskelig å anvende den praktiske og veldokumenterte forskningen i politikken?

I et teoretisk perspektiv handler implementering og endring mye om makt, autoritet, legitimitet, påvirkning, beslutningsprosesser, interesser, konflikt, skjulte prosesser, fortrolige samtaler, vanskelige beslutninger, uformelle samtaler, verdispørsmål, 
vilje, energi, motivasjon og kultur (Tronsmo, 2010). Dette er temaer som er vanskelig å forske på og synliggjøre, fordi forskerne får begrenset tilgang til slike data siden slik informasjon ikke er offentlig tilgjengelig annet enn på aggregert nivå. Derfor er det en stor utfordring å forsøke å summere opp kunnskap om implementering. Flere utdanningsforskere kommer inn på etikk i diskusjonen om styringen av utdanningssystemet (Ball, 2006; Biesta, 2010; Bottery, 1992). Felles for disse er et utgangspunkt der utdanning tilskrives en spesiell funksjon i samfunnet, moralsk sett, siden det skal være en aktivitet som ikke bare gjenskaper og forsterker trekk ved det bestående samfunnet, men en aktivitet som streber etter noe bedre - et nytt og bedre samfunn. Habermas (1969) advarte mot farene ved å la ideologi fylle kunnskapshullene. Han hevdet at dette fører til gap mellom kunnskapsgrunnlag og politikk, ved at retorikk skaper falske forestillinger og bilder av tilstander. Gap mellom kunnskapsgrunnlag og ideologi blir dermed lett til gap mellom intensjoner og resultater, fordi man implementerer en politikk på feil grunnlag.

Basert på resultater fra forskning, synes kunnskaper om reformenes målgrupper å være viktig for å minske gapet mellom de som initierer, og de som mottar en reform. Det gjelder å finne de riktige berøringspunktene til målgruppene, slik at de reagerer og berøres til valg og beslutninger som er forenelig med deres eget liv (Tønseth, 1998; Tønseth, 2011). Ikke som en 'governmentality' strategi, der man indirekte styrer folk til å tro at de tar egne valg og beslutninger gjennom å formidle til dem hva som er riktige valg, men derimot gjennom aktiv og lyttende dialog. Å tilrettelegge læring til voksnes ulike liv og vilkår, vil trolig også skape større presisjon i informasjonsarbeidet, rådgivningen og tilretteleggingen for den enkelte voksne.

\section{(2) Gap mellom likhet og mangfold, inkludering og ekskludering}

Denne kategorien inkluderer gap som handler om at man på den ene siden har intensjoner om utjevning av forskjeller når det gjelder utdanningsnivå og tilknytning til arbeidslivet, mens resultatene på den andre siden indikerer større ulikhet (Dale, Gilje \& Lillejord, 2011). I tillegg dreier det seg om formål om individualisering og tilrettelegging kontra resultater som viser en standardisering i store elevgrupper (Bie-Drivdal \& Harsvik, 2014; Langfeldt, 2008). Det handler også om intensjoner om inkludering, mens resultatene viser en større ekskludering.

Motstridende politisk verdigrunnlag, som i noen henseender bygger på likhet og i andre henseender bygger på mangfold, kan skape utfordringer fordi man har vanskelig for å enes om en omforent strategi (Hansen, 1999; Hansen \& Mastekaasa, 2003; OECD, 2004; NOU 2017:2). Idealet om likhet er representert ved intensjonen om å utjevne forskjeller og ulikhet, heve det generelle kompetansenivået i den norske befolkningen, og at alle skal gis samme tilgang og mulighet. Idealet om mangfold gjenfinnes i formål knyttet til økt individualisering ved at voksne skal få mulighet til å lære det de vil og har behov for, gjøre egne valg og få tilrettelagt læring for egne vilkår og livssituasjon (Bjørgen, 2000 s.74). OECD (2010) slår alarm om stadig 
$ø$ kende systematiske forskjeller og sosial ulikhet på alle nivå i utdanningssystemet. Det fokuseres sterkt på virkemidler som styrker inkludering og de individuelle mulighetene for utdanning og læring gjennom tilrettelegging av tilbud. En rapport fra EU (2006) påpeker at det mangler en klar strategi med en effektiv koordinering av tilbud og etterspørsel. Det mangler også fokus på ikke-yrkesrettede, uformelle formål, noe som utgjør en begrensning for å nå målet om 'livslang læring' for alle.

\section{(3) Gap mellom individrettede og kollektive intensjoner}

Denne kategorien omfatter både individrettede og kollektive mål, men samtidig fokus på begge viser seg å være vanskelig. Den inneholder gap mellom læringstilbud som er ment å være individrettet, men som begrenser voksnes muligheter for læring fordi de kollektive hensynene overfokuseres. Det handler også om intensjonene om $ø$ konomisk profitt og verdiskaping, samtidig som man ønsker å ivareta fellesverdier, individuell vekst og utvikling.

Reform 94, Kompetansereformen og Kunnskapsløftet ble alle planlagt og satt i verk i en periode under sterkt økonomisk relaterte føringer, hvor økonomiske intensjoner dominerte (jf. Rubenson, 2004). Biesta (2010, s.127) hevder at diskusjonen om læring og 'livslang læring' ikke i tilstrekkelig grad stiller spørsmålet om hva læringen skal være for. Utformingen av en politikk for å fremme livslang læring er begrunnet i både $ø$ konomiske, samfunnsmessige og individuelle hensyn. Evalueringer av reformene viser at dette er vanskelige formål å balansere og ivareta i praksis (Tønseth, 2011). I alle reformer handlet det mye om arbeidslivet som kontekst i berøring med utdanningsfeltet. Kritikken mot Kompetansereformen var blant annet at begrepet livslang læring mister mye av sin betydning. Kritikere mente at hvis læring skal være livslang og livsvid, så vil Kompetansereformen som kontekst være altfor snever. På denne måten drukner den tilsynelatende individualiseringen i den ensidige kollektive og samfunnsnyttige perspektivet, rettet mot økonomisk verdiskaping. Den økte utdanningskløften tyder på at mange voksne ikke får mobilisert og brukt sitt potensiale. Denne logikken innebærer at utdanningssystemet synes å vanskeliggjøre muligheten for de voksne til å tette gapet mellom deres livssituasjon og mulighetene utdanningssystemet gir dem (Tønseth, 2011). Saksvik et al., (2008) hevder at politikerne mangler en grunnleggende forstålse for hvordan mennesker reagerer på endringer. Uten denne forståelsen er det vanskelig å gjennomføre en vellykket endring.

\section{(4) Gap mellom formelle, ikke-formelle og uformelle læringskontekster}

Denne kategorien handler om vektleggingen av formelle læringskontekster der man ikke ser at ulike læringskontekster, og ulike former for læring, inngår i hverandre og er like viktig for resultatene (Coffield, 2000a). Formell læring foregår i kontekster som er organisert, strukturert og har formell kompetanse som mål, mens ikke-formell læring kan være strukturert, men uten formell kompetanse som mål. En stor del av 
slik ikke-formell læring skjer i arbeidslivet. Uformell læring er derimot egeninitiert læring som også omtales som hverdagslæring. Slik læring kan skje gjennom å lese bøker, se på tv, surfe på Internett, i samtale med venner og kollegaer osv. I alt dette inngår også voksnes realkompetanse og anerkjennelse av kunnskaper ervervet på ulike områder som like betydningsfulle som dokumentert formell kompetanse (Alfsen, 2016). Forskere innen voksnes læring og livslang læring viser en økende interesse for betydningen av uformell læring. Denne interessen har imidlertid ikke blitt reflektert på en signifikant måte i politiske sammenheng. Coffield (2000a, s. 1) hevder at fokuset forblir på formell læring, formelle læringskontekster og formelle kvalifikasjoner.

Å ta livslang og livsvid læring seriøst betyr å ta berøringspunktene mellom det formelle utdanningsfeltet og andre kontekster der voksne befinner seg, på alvor. Et grep der liv og lære blir vevd mer inn i hverandre åpner opp for læring i mange ulike kontekster. Det innebærer at alle kontekster er læringskontekster. Det åpner for at erfaringer på ett område lettere blir overførbare til andre. Coffield (2000b) hevder at uformell læring må ses som en fundamental, nødvendig og verdifull form for læring som noen ganger er relevant for arbeid og sysselsetting, og andre ganger ikke. Voksne deltar i mange ulike sammenhenger og kontekster, slik at det blir viktig å integrere læring som en naturlig del innenfor de ulike kontekstene der voksne deltar. Dette kopler sammen ulike områder innenfor voksnes læring: slik som uformell og formell læring, læring hjemme, på arbeidsplassen, via internett og gjennom ulike media og så videre.

Learning in different contexts may involve different types of learning. We might therefore need to question the extent to which, as educational researchers and pedagogic practitioners, we should try to overcome the gaps between learning in different strata. (Edwards, 2005)

\section{Politikkens heliumspråk}

Forskningsbasert kunnskap benyttes på ulike måter og i varierende grad som kunnskapsgrunnlag for å utforme og konstruere politikk på ulike områder. Eksempelvis i utdanningspolitikken (jf. Grønmo, 2004; Hølleland, 2008; Guba \& Lincoln, 1994). Med tanke på at forskningsbasert kunnskap produseres i et vitenskapssystem som følger en annen logikk enn politikkens eller praksisfeltets logikk, er det krevende å omsette vitenskapelig kunnskap til politisk planlegging. Tidsknapphet, tilgang på store mengder vitenskapelig informasjon, og ofte motstridende resultater/vitenskapelige utsagn, gjør heller ikke oppgaven lettere. Reformer i offentlig sektor er vanskelige å gjennomføre, de holder sjelden det de lover, de møter ofte mye motstand, de vedtas ofte raskt og det er stort sett lite samsvar mellom intensjoner og faktiske effekter (Peters, 2001; Pollitt \& Bouckaert, 2004). 
I utformingen av store reformer forsøker man enten å balansere motstridende verdier, eller formulerer mål som er så brede og vage at de forener mange verdier samtidig (Moen, 2011). Et godt eksempel på denne strategien finner vi i Kompetansereformens ambisjon om å balansere mellom likhet og fleksibilitet og mellom individrettede og kollektive målsettinger. Kompetansereformen hadde også som særegenhet at den hadde en sterk arbeidspolitisk side gjennom fagbevegelsens pådriverrolle, som helt klart hadde betydning for retorikk, forankring og implementering.

Et annet eksempel er tendensen til å fremheve både det instrumentelle i form av resultater, og det mer verdiforankrede i form av livskvalitet. De tre reformene har det til felles at språket er svært allment og flertydig. Det er mange grunner til at det er slik. For det første er dette en effektiv metode når man vil forene mange motstridende verdier samtidig. For det andre er reformene ofte en konsekvens av kompromisser, der et flertydig språk er velegnet for å få fram budskapet i disse kompromissene (Moen, 2011). I Kunnskapsløftet var det en sterk bevissthet om at det var viktig å være tydelig, og man trodde at det å være tydelig kunne redusere avstanden mellom reformens ideer og dens konkrete tiltak. Problemet er bare at reformer sjelden er tydelige, snarere er utydelighet et kjennetegn ved alle de tre reformene. Setninger og begreper er utpreget elastiske, og har et flertydig og diffust innhold (Tønseth, 2011). Siden reformideene er så abstrakte må de tolkes, og siden folk tolker ideer ulikt, opprettholdes avstanden mellom politiske intensjoner, praksis og resultater.

Kunnskapsdepartementet (2006) hevder at rasjonelt utformede organisasjonsstrukturer skal sikre utdanningssystemer av høy kvalitet, og at målet med Kunnskapsløftet var at alle elever skulle utvikle grunnleggende ferdigheter og kompetanse for å delta i kunnskapssamfunnet. Departementet kan absolutt ha rett i at rasjonelt utformede strukturer faktisk fører til høyere kvalitet, og at det er mulig å sørge for at alle elever får gode grunnleggende ferdigheter. Utsagnene kan likevel samtidig forstås som symboler som gjenspeiler uklarheter når det gjelder begreper som kvalitet, kunnskap, kompetanse.

Staunes et al. (2018) hevder at reformers språk karakteriseres av et heliumspråk. Et språk som sier alt og ingenting både på en åpen og samtidig autoritær måte (målformuleringer, grunnleggende ferdigheter, kompetanse, læringsutbytte, og så videre). Forfatterne hevder videre at de språklige «ballongførerne» i byråkratiet forsøker å løfte reformene språklig fra bakken ved å kaste tunge faglige sekkebegreper ut av korgen. Konsekvensene er at departement og politikerne mister detaljer og faglig bakkekontakt i styringen. Reformene flyr for høyt og uforpliktende med heliumbegrepene og ender i språklige luftslott.

Politikerekan ignorere forskning og lage analyser uten å inkludere motforestillinger og kritikk. Om resultatene blir dokumentert som dårlige, vil politisk ledelse sjelden ha evne til å se seg selv eller planene som årsak til dem, hevder Popper (1963, 1983). Popper kaller dette syndromet for gjenforsterket dogmatisme. Lederne vil lete etter syndebukker og utvikle konspirasjonsteorier fremfor å ta ansvar. Ut ifra et diskursperspektiv, kan man si at den dominerende ideologien som produseres 
gjennom de tre reformene innebærer en utdanningspositiv diskurs, der reformenes velgjørenhet er koplet sammen med samfunnets utvikling (økonomisk), som hevdes å bidra til livslang læring.

Retoriske formuleringer om, og argumentasjon rundt, betydningen av utdanning og læring omsettes til fakta ved at det eksempelvis påvises klar sammenheng mellom utdanningsnivå og evne til å ta vare på egen helse (Helsedirektoratet, 2010). Dette forhindrer ikke at den konkrete innsatsen på feltet et godt stykke på vei er omvendt proporsjonalt med retorikken. Grepperud (2011) hevder at ingen andre områder innen utdanningssektoren er så omgitt av uforpliktende visjoner som voksnes kvalifisering, med ditto problemer med å sette disse visjonene ut i livet. Grepprud et al. (2010) påpeker at det meste er som før, at intensjoner forblir intensjoner, og at reformene er en ytterligere bekreftelse på feltets marginalitet. De kompetanserelaterte ulikhetene innen voksnes læring fortsetter langs de samme skillelinjene som før, holdninger og perspektiver på kompetanse i norsk arbeidsliv er ikke endret. Målsetting om likestilling og utjevning ved å gi voksne rett til grunnopplæring er ikke nådd (Grepperud, 2011).

Politikkprosessen mot implementering av en utdanningsreform er preget av retorikk og debatt der viktigheten av å løse politiske utfordringer fremheves. Initiativtakere til en reform argumenterer og selger inn reformenes fortreffelighet i ulike fora gjennom et kunnskapsgrunnlag som gjerne er basert på en NOUutredning, og som gjennom sosial interaksjon i form av debatter i departement, regjering og storting blir til et felles reformgrunnlag.

Gjennom de evalueringer som er gjennomført i forbindelse med de tre reformene, kan det settes spørsmålstegn ved kunnskapsgrunnlaget som reformene bygger på, særlig når det gjelder hva som genererer deltagelse i læring blant ulike voksne, det vil si kunnskapen om reformenes strukturerende makt. Grepperud (2011) peker på avtagende engasjement og manglende helhetlig politikk for voksnes kvalifisering. En revitalisering av intensjonene overfor voksne må favne bredere, man må se med nye øyne på alle sider ved det man kaller voksenopplæringsfeltet: perspektiver, definisjoner, ansvar, finansiering, aktører, iverksetting og oppfølging.

Forventningen om at det ville være fruktbart å analysere reformpolitikk ut ifra et sosialkonstruksjonistisk perspektiv ble i høy grad innfridd for alle tre reformene. Forestillinger om virkeligheten, som er grunnlaget for reformene, skapes gjennom debatt, retorikk og argumentasjon som baserer seg på elementer fra forskning, praksis, kontekst, internasjonal politiske føringer og ideologi. Gjennomgangen viser at reformene gjenspeiler sosialt konstruerte normer om hva det vil si å være en «god reformaktør», og at departementet er opptatt av at reformenes aktører skal bli mest mulig konforme med disse normene. Reformer inneholder en rekke begreper som $\mathrm{i}$ utpreget grad er elastiske. Denne elastisiteten skaper flertydighet, og flertydigheten gjør at aktørene utvikler egne varianter av reformene. Reformene består av typiske vestlige modernitetsverdier som velges fordi myndighetene tror at det vil $\varnothing k e$ institusjonenes legitimitet. Dette får sterk støtte i tidligere forskning (Moen, 
2011). Tiltakene i reformene begrunnes med at de enten skal skape økonomisk vekst, konkurranseevne, fleksibilitet, likhet, mangfold, livskvalitet, skaperkraft og ansettbarhet. Alt dette representerer gode eksempler på «typiske modernitetsverdier». Bestrebelsene på å forene verdier som i utgangspunktet er svært ulike fører til at reformene domineres av mange brede anbefalinger og generelle råd (Moen, 2011).

\section{Konklusjon}

Gjennomgangen av tre utdanningsreformer har identifisert gap mellom kunnskapsgrunnlag og politikk, gap mellom likhet og mangfold, gap mellom inkludering og ekskludering, gap mellom individrettede og kollektive intensjoner og gap mellom formelle, ikke-formelle og uformelle læringskontekster. Som konklusjon kan vi si at de mange gapene mellom intensjoner og resultat som angår voksnes læring, blant annet handler om konstruksjon av en reformpolitikk der det benyttes kompromisser, abstrakte og vage formuleringer og elementer av ulike typer «evidens» som veves inn. Kunnskapsgrunnlaget som reformene bygger på, fremstår som fragmentert, med manglende kunnskap om reformenes strukturerende makt i tillegg til manglende kunnskap om hva stimulerer de ulike voksne til læring.

Denne dokumentanalysen understreker viktighet av ny forskning som støtter opp under et helhetlig, overbevisende og oppdatert kunnskapsgrunnlag når det gjelder voksnes ulike motiver, karriereønsker, behov og vilkår. Voksne som målgruppe blir stadig mer heterogen, og omfatter eksempelvis i stadig større grad innvandrere med sine behov og forutsetninger. Det trengs også mer kunnskap om hvilke strategier og tiltak som gir intenderte resultater når det gjelder inkludering i arbeids- og samfunnsliv, ikke som enkeltstående resultatmålinger, men gjennom grunnleggende og systematisk forskning. Det trengs også mer kunnskap om ulike læringskontekster der voksne deltar og sammenhengen mellom formell, non-formell og uformell læring. Videre må forskningen som gjøres tydeliggjøres på en slik måte at den utgjør et utvetydig fundament når ny politikk skal utformes. Formidling av forskning inn til ulike politiske fora kan ytterligere klargjøre forskningen og bidra til en mer enhetlig språk- og begrepsbruk også i politikkutforming. Gjentagende gap mellom intensjoner og resultater gjennom tre reformer peker også i retning av at det trengs større forpliktelser når det gjelder selve gjennomføringen av en politisk strategi.

\section{Referanser}

Aasen, P., Møller, J., Rye, E., Ottesen, E., Prøitz, T. S \& Hertzberg, F. (2012). Kunnskapsløftet som styringsreform - et løft eller et løfte? Sluttrapport. Oslo: NIFU. Universitetet i Oslo.

Alfsen, C. (2016). Country report Norway. 2016 update to the European Inventory on validation of non-formal and informal learning. CEDEFOP. 
Ball, S. J. (1994). Education Reform. A critical and post-structural approach. Buckingham: Open University Press.

Ball, S. J. (2006). Education Policy and Social Class, the selected works of Stephen J. Ball. Oxon: Routledge.

Berger, P. L. \& Luckmann, T. (1966). The Social Construction of Reality: A Treatise in the Sociology of Knowledge. Garden City, NY: Anchor Books.

Bie-Drivdal, A. \& Harsvik, T. (2014). Styring og maktforskyvning i utdanningssektoren om profesjonens handlingsrom og kollektive innflytelse. Temanotat 6/2014.

Utdanningsforbundet.

Biesta, G. J. J. (2010). Good Education in an age of Measurement. Ethics, Politics, Democracy. Colorado: Paradigm Publishers.

Bilson, A. (2002) (Red.). Evidence-based practice in Social Work. London: Whiting \& Birch Ltd. Bjørgen, I. A. (2000). Hva er viktig for læring i moden alder? I Raaheim, A. \& Raaheim, R. (Red.), Loring hos voksne. Bergen: Sigma.

Bottery, M. (1992). The Ethics of Educational Management: personal, social and political perspectives on educational management. London: Cassel.

Boeije, H. (2010). Analysis in Qualitative Research. Los Angeles/London/New Delhi/ Singapore/Washington DC: Sage Publications Ltd

Burr, V. (2006). An Introduction to Social Constructionism. London: Routledge.

Coffield, F. (2000a). General Themes and Policy Implications, introduction to second volume of ESRC. Learning Society findings. Bristol: Bristol Policy Press.

Coffield, F. (2000b). The Necessity of Informal Learning. Bristol: The Policy Press.

Cross, K. P. (1984). Adults as learners. San Fransisco: Jossey-Bass.

Cuban, L. (1993). How Teachers Taught. Constancy and Change in American Classrooms 18801990. New York: Teachers College Press.

Dahl, T., Buland, T., Mordal, S. \& Aaslid, B. E. (2012). På de samme stier som før: kunnskapsløftet i fag- og yrkesopploringen. Trondheim: SINTEF.

Dale, E. L., Gilje, N. \& Lillejord, S. (2011). Gjennomføring av utdanningsreformer $i$ utdanningssamfunnet. Oslo: Cappelen Damm.

Dale, E. L., Ulstrup Engelsen, B. \& Karseth, B. (2011). Kunnskapsløftets intensjoner, forutsetninger og operasjonaliseringer: en analyse av en loereplanform. Sluttrapport. Oslo: Universitetet i Oslo.

Datnow, A. (2000). Power and politics in the adoption of school reform models. Educational Evaluation and Policy Analysis, 22(4), 357-374.

Datnow, A. (2002). Can we transplant educational reform, and does it last? Journal of Educational Change, 3(3-4), 215-239.

Deichman-Sørensen, T. (1999). Reform 94 - fra implementering til reform? I Kvalsund, R. Deichman-Sørensen, T. \& Aamodt, P. O. (Red.), Videregående opploering - ved en skilleveg? Forskning fra den nasjonale evalueringen av Reform 94. Oslo: Tano Aschehoug.

Edwards, R. (2005). Contexts, boundary zones and boundary objects in lifelong learning. Paper presented at the British Educational Research Association Annual Conference, University of Glamorgan, 14-17 September. 
Elmore, R. F. (1996). Getting to scale with good educational practice. Harvard Educational Review, 66(1), 1-26.

Engesbak, H. (1995). Voksne i videregående. Reform 94 og konsekvenser for voksne. Evalueringsrapport 1/95. Trondheim: Norsk voksenpedagogisk forskningsinstitutt.

Engesbak, H., Finbak, L. \& Tønseth, C. (1998). På rett vei, uten rett. Reform 94 - konsekvenser for voksne. Rapport. Trondheim: Norsk voksenpedagogisk forskningsinstitutt.

Fejes, A. (2006). The planetspeak discourse of lifelong learning in Sweden: what is an educable adult? Journal of Education Policy, 21(6), 697-716.

Finbak, L. \& Engesbak, E. (2006). Å delta eller ikke delta. Om voksnes deltagelse i etter-og videreutdanning. Stavanger: Universitetet i Stavanger. Lesesenteret.

Foucault, M. (1999). Diskursens orden. Tiltredelsesforelesning 02.12.1970, Oslo: Spartacus Forlag AS.

Fudge C. \& Barrett S. M. (1981). Policy and Action: Essays on the Implementation of Public Policy. London: Methuen.

Fullan, M. (1999). Change Forces: The Sequel. Philadelphia, PA: Falmer Press, Taylor \& Francis Inc.

Fullan, M. (2001). Leading in a culture of change. San Francisco: Jossey-Bass/Wiley.

Giddens, A. (Red.) (2001). The Global Third Way Debate. Cambridge: Polity.

Grepperud, G. (2010). Kunnskapssamfunnet- hva vil vi med voksnes loering? Oslo: Gyldendal Akademisk.

Grepperud, G. (2011). Mer prat enn praksis- hva skjedde med Kompetansereformen. Bedre Skole. Vol 1.

Grøgaard, J. B., Midtsundstad, T. \& Egge, M. (1999). Følge opp - eller forfølge?: Evaluering av oppfølgingstjenesten i Reform 94. Fafo-rapport: 263. Oslo: Fafo.

Grøgaard, J. B., Markussen, E. \& Sandberg, N. (2002), Seks år etter: om kompetanseoppnåelse fra videregående opploering og overgang til arbeid og høyere utdanning for det første Reform 94 kullet. Rapport 3/2002. Oslo: NIFU.

Grønmo, S. (2004). Samfunnsvitenskapelige metoder. Bergen: Fagbokforlaget.

Guba, E. G. \& Lincoln, Y. S. (1994). Competing paradigms in qualitative research. I Denzin, N. K. \& Lincoln, Y. S. (Red.), Handbook of qualitative research (s. 105-117). Thousand Oaks, CA: Sage.

Habermas, J. (1969). Vitenskap som ideologi. Oslo: Gyldendal Norsk Forlag.

Hagen, A. \& Skule, S. (2008). Kompetansereformen og livslang loering. Status 2008. Faforapport 2008:07. Oslo: Fafo.

Hansen, H. F. (2007). Evidensbevægelsens idé og globale spredning. Forskningspolitikk nr. 2/2007.

Hansen, M. N. (1999). Utdanningspolitikk og ulikhet. Tidsskrift for samfunnsforskning, 2, 172-203.

Hansen, M. N. \& Mastekaasa, A. (2003). Utdanning, ulikhet og forandring. I I. Frønes \& L. Kjølsrød. (Red.), Det norske samfunn (4. utg.). Oslo: Gyldendal Akademisk.

Hargreaves, A. \& Fink, D. (2000). Three dimensions of educational reform. Educational Leadership, 57(7), 30-34. 
Helland, H. \& Opheim, V. (2004). Kartlegging av realkompetansereformen. Skriftserie 6/2004. Oslo: NIFU.

Helsedirektoratet (2010). Arbeid, helse og sosial ulikhet. Hefte 1/2010.

Hodgson, J., Rønning, W. \& Tomlinson, P. (2012). En studie av loereres praksis og deres tenkning under Kunnskapsløftet. Rapport. Tromsø: Nordlandsforskning.

Hølleland, H. (2008). Reformer som skaper reformer. Bedre skole, 4, 46-49.

Jørgensen, T. (2000), Sosiale skjevheter forsterkes gjennom utdanningssystemet. Samfunnsspeilet, 6/2000. Oslo - Kongsvinger: Statistisk sentralbyrå.

Høst, H. (2010). Fag- og yrkesopploeringen i Norge - noen sentrale utviklingstrekk. NIFUrapport $2 / 2010$

Klette, K. (2003). Reform policy and teacher professionalism in four Nordic countries. Journal of Educational Change. 3 (3-4), 265-282.

Knowles, M. S. (1988). The modern Practice of Adult education: from Pedagogy to Andragogy. Cambridge: Englewood Cliff, N. J.

Kunnskapsdepartementet (2006).... og ingen stod igjen. Tidlig innsats for livslang loering. Stortingsmelding nr. 16 (2006-2007).

Langfeldt, L. (2008). Kunnskap, utdanning og loering - hva loerte vi? Formidling av resultater. Oslo: Norges Forskningsråd.

Lødding, B. (1998). Med eller uten rett. Søkning, opptak og gjennomstrømning i videregående opploering blant tospråklige ungdommer og voksne etter Reform 94. Rapport 4/98. Oslo: NIFU.

Madsen, B. E. \& Tønseth, C. (1998). Trapes uten sikkerhetsnett. Om gjennomstrømning og frafall blant voksne elever $i$ videregående opploering. Evalueringsrapport 1/98. Trondheim: Norsk voksenpedagogisk forskningsinstitutt.

Moen, J. (2011). Om reformer. En studie av Kvalitetsreformen, Politireform $2000 \mathrm{og}$ Kunnskapsløftet (Doktoravhandling). Karlstad: Karlstad University Studies.

Nordenbo S. E. (2012). Kunnskapsløftet som reformproces. Aarhus: Aarhus Universitet.

NOU 1991:4. Veien videre til studie- og yrkeskompetanse for alle. Oslo: Kirke-, utdannings- og forskningsdepartementet.

NOU 1997:25. Ny kompetanse. Grunnlaget for en helhetlig etter-og videreutdanningspolitikk. Oslo: Kirke-, utdannings- og forskningsdepartementet.

NOU 2017: 2. Integrasjon og tillit - Langsiktige konsekvenser av høy innvandring. Oslo: Justisog beredskapsdepartementet.

OECD (2000). Tematisk gjennomgang av voksenopploering. Landrapport. Norge. Offisiell oversettelse fra engelsk. Paris: OECD.

OECD (2001). The Well-being of Nations. The Role of Human and Social Capital. Education and Skills. Paris: OECD.

OECD (2004). Equity in Education: Students with Disabilities, Learning Difficulties and Disadvantages. Paris: OECD.

OECD (2010). Lifelong learning for all. OECD Observer. Paris: OECD.

Olsen, O. J., Arnesen, E. C., Seljestad, L. O. \& Skarpenes, O. (1998). Fagopploering i omforming: sentrale mål og lokal virkelighet Evaluering av Reform 94. Sluttrapport. Universitetet i Bergen.

Peters, G. (2001). The Politics of Bureaucracy. (5th edition). London: Routledge. 
Pollitt, C. \& Bouckaert, G. (2004). Public management reform: A comparative analysis. USA: Oxford University Press.

Popper, K. R. (1963). Conjectures and Refutations. London: Routledge.

Popper, K. R. (1983). Realism and the aim of science. London: Routledge.

Rubenson, K. (2004). Lifelong learning: a critical assessment to the political project. I P. Alheit, R.Becker-Schmidt, T. Gitz-Johansen, L. Ploug, H. Salling Olesen og K. Rubenson. (Red.), Shaping an emerging reality. Researching lifelong learning. Roskilde: Roskilde University press, s. 28-47.

Røed, K. (1993). Den selvforsterkende arbeidsledigheten. Om hystereseeffekter i arbeidsmarkedet. SSB rapport 93/19.

Saksvik, P. Ø., Nytrø, K. \& Tvedt, S. D. (2008). Sunn endring i organisasjoner. I Tidsskrift for Norsk Psykologiforening, 45 (3), 295-300.

St.meld. nr. 42 (1997-98). Kompetansereformen. Oslo: Kirke-, utdannings- og forskningsdepartementet.

St.meld.nr.30 (2003-2004). Kultur for loering. Oslo: Utdannings- og forskningsdepartementet. Støren, L. A., Skjærsli, S. \& Aamodt, P. O. (1998). I mål? Evaluering av Reform 94. Sluttrapport fra NIFUs hovedprosjekt. NIFU-rapport; 18/1998. Oslo: Norsk institutt for studier av forskning og utdanning.

Støren, L. A. \& Sandberg, N. (2001). Gjennomstrømning i videregående opploering 1994-1999. Videreføring av evalueringen av Reform 94. NIFU skriftserie 8/2001. Oslo: Norsk institutt for studier av forskning og utdanning.

Svensen, E. (2000), En voksen krysser sitt spor. Motivasjon for deltakelse i grunnskoleopploering. Fafo-rapport: 340. Oslo: Fafo.

Sætren H. (2006). Facts and Myths About Research on Public Policy Implementation: Out-of fashion, Allegedly Dead, But Still Very Much Alive and Relevant. The Policy Studies Journal, 33(4), 559-582.

Teige, B. K., Finne. H., Tønseth, C., Solbak, T. L. \& Buland, T. (2009). Kunnskapsløftet på reise II: Andre delrapport. Trondheim: SINTEF.

Thagaard, T. (2002). Systematikk og innlevelse: En innføring i kvalitativ metode. Bergen: Fagbokforlaget, 2. utgave.

Tronsmo, P. (2010). Ledelse i utdanningssektoren. Bedre skole, 1, 62-67.

Tyack, D. \& Cuban, L. (1995). Tinkering toward Utopia. A Century of Public School Reform. Cambridge, Mass.: Harvard University Press.

Tønseth, C. (1998). Voksne i fritt svev i Reform 94. Curriculum Vitae (CV). Tidsskrift for folkeopplysning og voksnes loering - i lys av kultur, politikk og pedagogikk. Nr 1/98.

Tønseth, C. (1999). Et fleksibelt og tilrettelagt opplæringssystem for voksne. Sentrale utfordringer. I R. Kvalsund, T. Deichman Sørensen \& P. O. Aamodt (Red.), Videregående opploering - ved en skilleveg? Forskning fra den nasjonale evalueringen av Reform 94. Oslo: Tano Aschehoug.

Tønseth, C. (2011). Voksne i loering. Identitetskonstruksjon i lys av Kompetansereformen

(Doktoravhandling). Institutt for sosiologi og statsvitenskap. Trondheim: Norges 
teknisk -naturvitenskapelige universitet, Fakultet for samfunnsvitenskap og teknologiledelse, Institutt for sosiologi og statsvitenskap.

UFD. (2003). Education for All - National Action Plan for Norway in accordance with the World Education Forum Declaration, Dakar, 2001. Oslo: the Ministry of Education and Research Affairs.

Ulleberg, H. P. (2007). Diskursanalyse: et mulig bidrag til utdanningshistorisk forskning. I Barn, Vol 1. Trondheim: Norsk senter for barneforskning.

Vibe, N., Frøseth, M. W., Hovdhaugen, E. \& Markussen, E. (2012). Strukturer og konjunkturer: evaluering av Kunnskapsløftet: sluttrapport fra prosjektet Tilbudsstruktur, gjennomføring og kompetanseoppnåelse i videregående opplaering. Sluttrapport. Oslo: NIFU. 